Jeanne O Madrid., M.D.'

Celso V. Ureta, M.D. ${ }^{1,2}$

'Department of Otorhinolaryngology

Head and Neck Surgery

Veterans Memorial Medical Center

${ }^{2}$ Department of Otorhinolaryngology Head and Neck Surgery

Manila Central University - Filemon D. Tanchoco

Medical Foundation (MCU-FDTMF)
Correspondence: Jeanne O. Madrid, M.D.

Department of Otorhinolaryngology Head and Neck Surgery

Veterans Memorial Medical Center

North Avenue, Diliman, Quezon City 0870

Philippines

Telephone: (632) 927-6426 local 1359

Telefax: (632) 426-9775

e-mail address:enthns_vmmc@yahoo.com

Reprints will not be available from the author.

No funding support was received for this study. The authors signed a disclosure that they have no proprietary or financial interest with any organization that may have a direct interest in the subject matter of this manuscript, or in any product used or cited in this article.

Presented at the Descriptive Research Contest (1st place) Philippine Society of Otolaryngology - Head and Neck Surgery, Jade Valley Restaurant, Quezon City, September 25,

\section{Videostroboscopic Evaluation of Neoglottis in Alaryngeal Patients after Tracheoesophageal Voice Reconstruction without Prosthesis}

\begin{abstract}
Objective: To investigate by means of videostoboscopy the characteristics of the neoglottis after total laryngectomy with primary or secondary voice reconstruction using a non-prosthetic tracheoesophageal fistula technique.
\end{abstract}

\section{Methods:}

\author{
Design: Cross-Sectional Study \\ Setting: Tertiary Public Hospital \\ Subjects: Twenty alaryngeal patients
}

Results: Videostroboscopy enabled evaluation of the neoglottis in all but two patients with a pectoralis major myocutaneous flap reconstruction of the pharyngoesophageal segment. Pooling of saliva was present in the cranial neoglottic opening in all subjects, but obscured visualization in these two. A circular neoglottic shape was most commonly seen. Vibration of the neoglottis was noted in $90 \%$ of all alaryngeal patients and was associated with a regular mucosal wave. Pharyngoesophageal vibration was noted in two thirds of patients. It was associated with a strong mucosal wave, regular vibration and a longer open phase.

Conclusion: Videostroboscopy confirmed that neoglottic vibration accompanies sound production while pharyngoesophageal vibration may reinforce and enhance voice production in alaryngeal patients with non-prosthetic TE voice reconstruction.

Keywords: larynx, total laryngectomy, voice reconstruction, tracheoesophageal (te) fistula speech, alaryngeal voice, alaryngeal speech, videostrobe

Alaryngeal patients may reacquire their voice through electronic voice resonators, implants, esophageal speech, and tracheoesophageal (TE) fistula with and without prosthesis (e.g. Blom- 
Singer ${ }^{\circledast}$, Provo $\left.^{\circledast}\right)$. In the Philippine setting, TE fistula prostheses are associated with complications of infection and foreign body ingestion and frequent prosthesis replacement is costly and unavailable. Hence, non-prosthetic tracheoesophageal (TE) fistula speech provides a viable option in relation to voice character, cost, practicability and availability. ${ }^{1}$

Tracheoesophageal fistula speech has been perceived as superior to electrolaryngeal or traditional esophageal speech, even though it is not viewed as comparable to the normal voice. It has been found not to differ significantly from normal speech in intelligibility, rate and inflection, but is less acceptable for fluency, pitch/quality and overall acceptability. ${ }^{2}$

Primary or secondary Veterans Memorial Medical Center / Manila Central University Medical Foundation Celso Ureta (VMCU) technique voice reconstruction employs TE fistula voice rehabilitation that does not use prosthesis and is a modified Amatsu voice reconstruction technique. It utilizes a funnel shaped TE fistula that serves as the neoglottis. This has been a standard voice reconstruction technique in our institutions for more than a decade.

A series of events occurs during TE phonation. To initiate voice production, the patient takes a deep breath, covers the tracheostoma with digital pressure and speaks like a normal person does. Tracheostomal occlusion directs pulmonary air through the TE fistula into the esophagus. Air passing through the TE fistula sets off neoglottic vibration and cricopharyngeal muscle constriction and the resultant sound is converted to understandable speech by the intact articulatory structures. $^{3}$

Previous studies on anatomical and morphologic characteristics of the neoglottis have focused on TE speech with prosthesis (BlomSinger ${ }^{\circledast}$, Provo ${ }^{\circledast}$ ) using videofluoroscopy, fiberoptic visualization and videostroboscopy and incorporate further assessment with perceptual evaluation, acoustic analyses and digital high-speed imaging. ${ }^{4}$

PubMED with Philippine Index Medicus and HERDIN database searches using "larynx," "alaryngeal voice," "alaryngeal speech," "tracheoesophageal fistula speech," "videostrobe" MeSH terms did not yield a videostroboscopic study on the anatomical and morphologic characteristics of the neoglottis for non-prosthetic tracheoesophageal fistula speech.

This paper aims to investigate by means of videostroboscopy the various characteristics of the neoglottis after total laryngectomy with primary or secondary voice reconstruction using a non-prosthetic TE fistula or VMCU technique. Specifically, it aims to enumerate the videostroboscopic findings and describe the anatomical and morphologic characteristics of the neoglottis; gain insight into the underlying mechanism of voice production; and provide recommendations for videostroboscopic evaluation in these patients.

\section{MATERIALS AND METHODS}

Informed consent was sought from adult alaryngeal patients who underwent total laryngectomy with primary or secondary VMCU nonprosthetic TE voice reconstruction technique between 1997 and 2008.

Included were patients who underwent total laryngectomy with or without hypopharyngectomy and partial esophagectomy and reconstruction using pectoralis major myocutaneous flap. Patients who had active pulmonary tuberculosis or who did not consent to the study were excluded.

Twenty subjects meeting inclusion criteria consisted of 19 males and one female with age varying from 49 to 78 years (mean, 63 years). Five patients had Stage III and 15 had Stage IV squamous cell carcinoma of the larynx. ${ }^{5}$ A total laryngectomy was performed in all 20 patients. In two patients, the pharynx was reconstructed partially with a pectoralis major myocutaneous flap. Nineteen patients underwent primary TEF reconstruction while one patient underwent secondary TEF reconstruction 1.5 years post total laryngectomy. All 20 patients underwent neck dissection and postoperative radiotherapy. In two patients, videostroboscopic examination was performed three weeks shortly after completion of radiotherapy. The rest of the patients were assessed six months or longer post-radiotherapy (Table 1).

A flexible fiberoptic Olympus ENF P3 nasopharyngolaryngoscope (Olympus-Optical, Japan) with a Kay Elemetrics Videostroboscopy system MODEL 9100 S (Kay Elemetrics Corp., Lincoln Park, NJ USA) was utilized for all patients, following five minutes decongestion and topical anesthesia with intranasal gauze strips soaked in $0.05 \%$ Oxymetazoline Hydrochloride nasal spray (Schering Plough, East Java, Indonesia) and 10\% Lidocaine topical spray (Astra Zeneca AB, Sodertalje, Sweden). Two patients with strong gag reflexes were given additional topical $10 \%$ lidocaine spray per os during the recording examination. A contact microphone was secured to the neck superior to the stoma, utilizing the standard Velcro (Velcro Industries B.V., Manchester, NH USA) strap.

A single consultant otolaryngologist performed the endoscopy on all patients. Transnasal flexible videostroboscopy of the hypopharynx and upper esophagus showing neoglottic activity during quiet breathing and voicing was performed. Patients were asked to produce a sustained vowel /a/ and /e/ sound after the cranial opening of the neoglottis was visualized. Digital stomal occlusion using the first digit was performed by all patients during phonation.

Sequences were stored on a computer hard disk and replayed at delayed speeds down to single frame display, using the Kay Elemetrics 


\section{Table 1. Profile of Alaryngeal Patients who Underwent Tracheoesophageal Voice Reconstruction without Prosthesis included in the Videostroboscopic Evaluation of Neoglottis}

\begin{tabular}{ll}
\hline \multicolumn{1}{l}{ Characteristics } & Mean or Proportion (N=20) \\
\hline Age & 63 years (range 49-78) \\
Male & $19(95 \%)$ \\
\hline Tumor Stage (AJCC): & \\
$\quad$ Stage III & $5(25 \%)$ \\
$\quad$ Stage IV & $15(75 \%)$ \\
Total laryngectomy with neck dissection & \\
$\quad$ w/o reconstruction & $18(90 \%)$ \\
$\quad$ with pectoralis major myocutaneous flap reconstruction & $2(10 \%)$ \\
Tracheo-esophageal fistula & \\
$\quad$ Primary surgery & $18(90 \%)$ \\
$\quad$ Second stage surgery & $2(10 \%)$ \\
Time of videostroboscopy evaluation from surgery & 3 weeks to 9 years \\
\hline
\end{tabular}

software program (Kay Elemetrics Corp., Lincoln Park, NJ USA).

Definitions of the variables used for videostroboscopic assessment of the neoglottis were elucidated and modified for non-prosthetic TE fistula and the stroboscopic assessment form used for TE fistula with prosthesis suggested by Hirano and Bless ${ }^{6}$ (Appendix $1 A$ ) was modified for use in this study and is found in Appendix $1 B$.

\section{RESULTS}

Videostroboscopy enabled evaluation of the neoglottis in all except two patients with a pectoralis major myocutaneous flap reconstruction of the pharyngoesophageal segment. Results utilizing the modified Hirano and Bless assessment form for the videostroboscopic evaluation of the neoglottis without tracheoesophageal prosthesis are listed in Table 2.

Although pooling of saliva was present in the cranial neoglottic opening in all subjects, it obscured visualization in the two patients with PMMF reconstruction. These patients also produced "wet voices," but they were still comprehensible. In 15/20 patients, there was only little to moderate amount of visible saliva. None of the patients had associated gross aspiration.

The average frequency for phonation of sustained vowel /e/ was 91.5 Hertz at an average amplitude of 64.5 decibels and an average duration of four seconds. For sustained vowel/a/, the average frequency was 83.5 Hertz at an average amplitude of 66.5 decibels and an average duration of 3.5 seconds. The lone female subject exhibited the same fundamental frequency as her male counterparts. Table 3 lists the mean frequency, amplitude and duration of neoglottis during sustained vowel /e/ and /a/ phonation.

The neoglottis during phonation assumed a circular shape in $8 / 20$
Table 2. Videostroboscopic Evaluation of the Neoglottis without Tracheoesophageal Prosthesis using the Modified Hirano and Bless Assessment Form

\begin{tabular}{|c|c|c|c|c|}
\hline \multirow{3}{*}{ Variable } & \multirow{3}{*}{ Judgment } & \multicolumn{3}{|c|}{ STANDARD TOTAL LARYNGECTOMY } \\
\hline & & & \multicolumn{2}{|c|}{$\begin{array}{l}\text { Pharyngoesophagectomy } \\
\text { with Pectoralis Major Flap } \\
\text { (PMMF) Reconstruction }\end{array}$} \\
\hline & & \multicolumn{3}{|c|}{ VOICE RECONSTRUCTION } \\
\hline \multirow{5}{*}{ Assessability } & \multirow{5}{*}{$\begin{array}{l}\text { Good } \\
\text { Fair } \\
\text { Moderate } \\
\text { Poor }\end{array}$} & Primary & Secondary & Primary \\
\hline & & 16 & 1 & 1 \\
\hline & & 1 & & 1 \\
\hline & & & & \\
\hline & & & & \\
\hline \multirow[t]{4}{*}{ Brightness } & \multirow{4}{*}{$\begin{array}{l}\text { Good } \\
\text { Fair } \\
\text { Moderate } \\
\text { Poor }\end{array}$} & 16 & 1 & 1 \\
\hline & & 1 & & 1 \\
\hline & & & & \\
\hline & & & & \\
\hline \multirow[t]{2}{*}{ Focus } & \multirow{2}{*}{\begin{tabular}{l|} 
Focused \\
Slightly unfocused \\
Unfocused
\end{tabular}} & 17 & 1 & 2 \\
\hline & & & & \\
\hline \multirow{5}{*}{ Saliva } & \multirow{5}{*}{$\begin{array}{l}\text { None } \\
\text { A little } \\
\text { Moderate } \\
\text { Much } \\
\text { Obstructing }\end{array}$} & & & \\
\hline & & 9 & 1 & \\
\hline & & 5 & & \\
\hline & & 2 & & 1 \\
\hline & & 1 & & 1 \\
\hline \multirow{2}{*}{$\begin{array}{l}\text { Visibility of the origin of } \\
\text { the neoglottis }\end{array}$} & \multirow{2}{*}{$\begin{array}{l}\text { Visible } \\
\text { Not visible }\end{array}$} & 17 & 1 & \\
\hline & & & & 2 \\
\hline \multirow[t]{7}{*}{ Shape of the neoglottis } & \multirow{7}{*}{$\begin{array}{l}\text { Circular } \\
\text { Triangular } \\
\text { Split side-to-side } \\
\text { Split anterior-pos- } \\
\text { terior } \\
\text { Irregular } \\
\text { Not assessable }\end{array}$} & 7 & 1 & \\
\hline & & 3 & & \\
\hline & & 2 & & \\
\hline & & 5 & & \\
\hline & & & & \\
\hline & & & & 2 \\
\hline & & & & 1 \\
\hline \multirow{3}{*}{$\begin{array}{l}\text { Presence of neoglottic } \\
\text { mucosal wave }\end{array}$} & \multirow{3}{*}{$\begin{array}{l}\text { Strong } \\
\text { Weak } \\
\text { Absent }\end{array}$} & 15 & 1 & 1 \\
\hline & & 2 & & \\
\hline & & & & 1 \\
\hline \multirow{3}{*}{$\begin{array}{l}\text { Regularity of neoglottic } \\
\text { vibration }\end{array}$} & \multirow{3}{*}{$\begin{array}{l}\text { Regular } \\
\text { Irregular } \\
\text { Not assessable }\end{array}$} & 15 & 1 & 1 \\
\hline & & 2 & & \\
\hline & & & & \\
\hline \multirow{5}{*}{$\begin{array}{l}\text { Location of the visible } \\
\text { pharyngoesophageal } \\
\text { vibration }\end{array}$} & Posterior & & & \\
\hline & Anterior & & & \\
\hline & 2 or 3 walls & 10 & 1 & 2 \\
\hline & All walls & 7 & & \\
\hline & Not assessable & & & 1 \\
\hline Presence of pharyn- & Strong & 15 & 1 & 1 \\
\hline goesophageal mucosal & Weak & 2 & & \\
\hline wave & Absent & & & \\
\hline Regularity of pharyn- & Regular & 15 & 1 & 2 \\
\hline goesophageal vibration & Irregular & 2 & & \\
\hline & Not assessable & & & \\
\hline Closure phase & Open & 17 & 1 & 2 \\
\hline & Equal & & & \\
\hline & Closed & & & \\
\hline & Not assessable & & & \\
\hline
\end{tabular}


ORIGINAL ARTICLES

Table 3. Mean frequency and amplitude of sustained vowel $/ \mathrm{e} / \mathrm{and} / \mathrm{a} /$ and mean duration of neoglottic vibration on phonation

\begin{tabular}{|c|c|c|c|c|c|c|}
\hline \multirow{2}{*}{$\begin{array}{l}\text { Voice } \\
\text { Characteristics } \\
(\mathrm{N}=20)\end{array}$} & \multicolumn{2}{|c|}{$\begin{array}{l}\text { Neoglottic Frequency } \\
\text { (Hertz) }\end{array}$} & \multicolumn{2}{|c|}{$\begin{array}{l}\text { Neoglottic Amplitude } \\
\text { (Decibels) }\end{array}$} & \multicolumn{2}{|c|}{$\begin{array}{l}\text { Neoglottic vibration } \\
\text { duration (Seconds) }\end{array}$} \\
\hline & |e/ & $|a|$ & |e/ & $|a|$ & |e/ & $|a|$ \\
\hline Mean & $91.5 \mathrm{~Hz}$ & $83.5 \mathrm{~Hz}$ & $64.5 \mathrm{~dB}$ & $66.5 \mathrm{~dB}$ & $4.0 \mathrm{~s}$ & $3.5 \mathrm{~s}$ \\
\hline $\begin{array}{l}\text { Standard } \\
\text { deviation }\end{array}$ & $12.6 \mathrm{~Hz}$ & $12.3 \mathrm{~Hz}$ & $10.7 \mathrm{~dB}$ & $10.7 \mathrm{~dB}$ & $1.3 \mathrm{~s}$ & $1.2 \mathrm{~s}$ \\
\hline
\end{tabular}

Appendix IA. Hirano and Bless Assessment Form of the Videostroboscopic Evaluation of the Neoglottis with Tracheoesophageal Prosthesis

\begin{tabular}{|c|c|c|c|c|c|c|}
\hline \multirow{2}{*}{$\begin{array}{l}\text { Variables } \\
\text { Assessability }\end{array}$} & \multicolumn{6}{|c|}{ Rating } \\
\hline & Good & Fair & Moderate & Poor & & \\
\hline Brightness & Good & Fair & Moderate & Poor & & \\
\hline Focus & Focused & $\begin{array}{l}\text { Slightly } \\
\text { unfocused }\end{array}$ & Unfocused & & & \\
\hline Saliva & None & A little & Moderate & Much & Obstructing & \\
\hline $\begin{array}{l}\text { Visibility of the } \\
\text { origin of the } \\
\text { neoglottis }\end{array}$ & Visible & Not visible & & & & \\
\hline $\begin{array}{l}\text { Shape of the } \\
\text { neoglottis or } \\
\text { vibrating part }\end{array}$ & Circular & Triangular & $\begin{array}{l}\text { Split side-to- } \\
\text { side }\end{array}$ & \begin{tabular}{|l} 
Split \\
anterior- \\
posterior \\
\end{tabular} & Irregular & $\begin{array}{l}\text { Not } \\
\text { assessable }\end{array}$ \\
\hline $\begin{array}{l}\text { Location of the } \\
\text { visible vibration }\end{array}$ & Posterior & Anterior & Left & Right & All walls & $\begin{array}{l}\text { Not } \\
\text { assessable }\end{array}$ \\
\hline $\begin{array}{l}\text { Presence of } \\
\text { mucosal wave }\end{array}$ & Strong & Weak & Absent & & & \\
\hline $\begin{array}{l}\text { Regularity of } \\
\text { vibration }\end{array}$ & Regular & Irregular & $\begin{array}{l}\text { Not } \\
\text { assessable }\end{array}$ & & & \\
\hline Closure phase & $\begin{array}{l}\text { Open phase } \\
\text { predom- } \\
\text { inates }\end{array}$ & Equal & $\begin{array}{l}\text { Closed } \\
\text { phase } \\
\text { predom- } \\
\text { inates }\end{array}$ & $\begin{array}{l}\text { Not } \\
\text { assessable }\end{array}$ & & \\
\hline
\end{tabular}

(40\%) followed by antero-posterior split in $5 / 20(25 \%)$, triangular in $3 / 20(15 \%)$ and a side-to-side split in $2 / 20(10 \%)$. An irregularly shaped neoglottis was not noted. Since the neoglottis of two patients reconstructed with PMMF was not visible, its shape could not be assessed.

A neoglottic mucosal wave was present in 18/20 (90\%) and strongly visible and regular in $16 / 20(80 \%)$ of the patients. The mucosal wave could not be assessed in the two patients with PMMF reconstruction.

Transnasal flexible videostroboscopic view of the hypopharynx and upper esophagus showed two bulges in the pharyngoesophageal (PE) segment, which was also noted to vibrate. The vibration involved two to three walls of the PE segment in 11/20 (55\%) and involved all walls in
9/20 (45\%) of cases. A strong PE mucosal wave was seen in 17/20 (85\%), regular PE vibration was observed in $16 / 20(80 \%)$ and a longer open phase of the PE segment was noted in all 20/20 (100\%).

In patients wherein the pharynx was reconstructed using a pectoralis major myocutaneous flap, upper pharyngoesophageal vibration was noted in all walls. Characteristic wet voice was notably persistent throughout the examination; though less comprehensible, speech was still achieved by non-prosthetic TE fistula speech in these patients.

\section{DISCUSSION}

Requirements for normal phonation are adequate breath support, approximation of vocal folds, favorable vibratory properties, favorable vocal fold shape and control of length and tension.? In alaryngeal phonation, the neoglottis takes up vocal fold function. The neoglottic mucosa covering muscle, mucosal wave, length and tension change on phonation are similar to those of a normal glottis. This resemblance enables alaryngeal patients to phonate.

Although the anatomy and morphology of the new voice source (neoglottis) were highly variable, what was consistent in this study was that most patients had a neoglottic vibration and mucosal wave, which could be identified even in patients evaluated shortly after surgery. The consistent findings of neoglottic vibration and mucosal wave in our study confirms previous studies showing the neoglottis as the source of vibration during tracheoesophageal (TE) phonation without prosthesis. ${ }^{8}$

The neoglottis has no uniform anatomical size or shape during phonation. ${ }^{9}$ Its variable shape and length are outcomes of hypopharyngeal and upper esophageal reconstruction. ${ }^{10}$ Wound healing and fibrosis contribute to this occurrence. Pharyngeal defects with PMMF reconstruction further complicate the neoglottic appearance.

The frequency and amplitude of the non-prosthetic TE fistula reinforces findings that the neoglottis functions similarly to true vocal cord. Our findings suggest that the non-prosthetic TE fistula may be better than TE fistulae with prosthesis, as the latter potentially obscure and dampen the neoglottic mucosal wave by mere presence in the fistula. Actual comparative studies may elucidate our suggestion.

The neoglottis does not have the flexibility and volitional controllability of the glottis and its frequency and amplitude have limited range in vocal pitch compared with normal true vocal cords. ${ }^{9}$ The human vocal range in terms of frequency is $90-250$ Hertz for normal male and female voices ${ }^{11}$ while the average range for both males and the sole female in our study was 83.5-91.5 Hertz.

Pooling of saliva was seen in all neoglottic openings, but was greater 
in patients with hypopharyngeal reconstruction, resulting in breathy, wet voices and less understandable speech. This may be attributed to a disturbance in the peristaltic and mucosal wave movement of the pharyngoesophageal segment due to PMMF reconstruction of the hypopharynx and esophagus, causing retention and difficult ingestion of saliva. ${ }^{12}$

Vibration in other parts of the cricopharynx further reinforces the vibratory function and enhances voice production. ${ }^{12}$ Of the two bulges seen in the pharyngoesophageal segment, the upper bulge formed by the cricopharyngeal muscle is an ancillary sound source of the nonprosthetic TE shunt while the lower bulge corresponds to the upper esophageal muscle sphincter. Anteroposterior and undulating regular movements have been observed in the PE segment by other authors. ${ }^{10}$

AppendixIB. Modified Hirano and Bless Assessment Form of the Videostroboscopic Evaluation of the Neoglottis without Tracheoesophageal Prosthesis

\begin{tabular}{|c|c|c|c|c|c|c|}
\hline Variables & & & Rat & & & \\
\hline Assessability & Good & Fair & Moderate & Poor & & \\
\hline Brightness & Good & Fair & Moderate & Poor & & \\
\hline Focus & Focused & $\begin{array}{l}\text { Slightly } \\
\text { unfocused }\end{array}$ & Unfocused & & & \\
\hline Saliva & None & A little & Moderate & Much & Obstructing & \\
\hline $\begin{array}{l}\text { Visibility of the } \\
\text { origin of the } \\
\text { neoglottis }\end{array}$ & Visible & Not visible & & & & \\
\hline $\begin{array}{l}\text { Shape of the } \\
\text { neoglottis or } \\
\text { vibrating part }\end{array}$ & Circular & Triangular & $\begin{array}{l}\text { Split side-to- } \\
\text { side }\end{array}$ & $\begin{array}{l}\text { Split } \\
\text { anterior- } \\
\text { posterior }\end{array}$ & Irregular & $\begin{array}{l}\text { Not } \\
\text { assessable }\end{array}$ \\
\hline $\begin{array}{l}\text { Location of the } \\
\text { visible vibration }\end{array}$ & Posterior & Anterior & Left & Right & All walls & $\begin{array}{l}\text { Not } \\
\text { assessable }\end{array}$ \\
\hline $\begin{array}{l}\text { Presence of } \\
\text { neoglottic } \\
\text { mucosal wave }\end{array}$ & Strong & Weak & Absent & & & \\
\hline $\begin{array}{l}\text { Regularity of } \\
\text { neoglottic } \\
\text { vibration }\end{array}$ & Regular & Irregular & $\begin{array}{l}\text { Not assess- } \\
\text { able }\end{array}$ & & & \\
\hline $\begin{array}{l}\text { Location of the } \\
\text { visible pharyn- } \\
\text { goesophageal } \\
\text { vibration }\end{array}$ & Posterior & Anterior & 2 or 3 walls & All walls & $\begin{array}{l}\text { Not assess- } \\
\text { able }\end{array}$ & \\
\hline $\begin{array}{l}\text { Presence } \\
\text { of pharyn- } \\
\text { goesophageal } \\
\text { mucosal wave }\end{array}$ & Strong & Weak & Absent & & & \\
\hline $\begin{array}{l}\text { Regular- } \\
\text { ity of pharyn- } \\
\text { goesophageal } \\
\text { vibration }\end{array}$ & Regular & Irregular & $\begin{array}{l}\text { Not assess- } \\
\text { able }\end{array}$ & & & \\
\hline Closure phase & $\begin{array}{l}\text { Open phase } \\
\text { predom- } \\
\text { inates }\end{array}$ & Equal & $\begin{array}{l}\text { Closed phase } \\
\text { predom- } \\
\text { inates }\end{array}$ & $\begin{array}{l}\text { Not assess- } \\
\text { able }\end{array}$ & & \\
\hline
\end{tabular}

Videostroboscopic fiberoptic endoscopy confirms that TE phonation has two steps, consistent with previous studies. ${ }^{3}$ First, the preparatory stage of hypopharyngeal closure which forms a small lumen. Second, the phonatory stage of the vibration of the neoglottis with a definite configuration maintained by hypopharyngeal muscle contraction.

Our study confirmed that the neoglottis vibrates to produce sound while the pharygoesophageal segment reinforces vibratory function and enhances voice production in alaryngeal patients with nonprosthetic tracheoesophageal voice reconstruction. Neoglottic voice analysis can be measured by videostroboscopy in terms of frequency, amplitude and duration. While the Hirano and Bless videostroboscopic assessment form was readily adaptable to evaluation of TE fistula patients without prosthesis, further studies may be conducted to validate our modification of this instrument, as well as its application in evaluating speech rehabilitation among a larger sample of these patients.

\section{REFERENCES}

1 Ureta CV. Primary voice reconstruction in total laryngectomy patients. Philippine Scientific Journal. 2002 Jan-Dec; 1: 5-6.

2 Pindzola RH, Cain BH. Acceptability ratings of tracheoesophageal speech. Laryngoscope. 1988 Apr;98(4):394-7.

3 Mohri M, Yoshifuji M, Kinishi M, Amatsu M. Neoglottic activity in tracheoesophageal phonation. Auris Nasus Larynx. 1994;21(1):53-8.

4 van As CJ, Op de Coul BMR, van den Hoogen FJA, Koopmans-van Beinum FJ, Hilgers FJM. Quantitative videofluoroscopy a new evaluation tool for tracheoesophageal voice production. Arch Otolaryngol Head Neck Surg. 2001;127:161-169.

5 Greene FL, Page DL, Fleming ID, Fritz AF, Balch CM, Haller DG, Morrow M. American Joint Committee on Cancer: AJCC Cancer Staging Manual. New York: Springer, 6th ed., 2002. pp 8088.

6 Hirano M, Bless DM. Videostroboscopic Evaluation of the Larynx. San Diego, CA: Singular Publishing Group; 1993.

7 Cummings CW, Flint PW, Haughey BH, Robbins KT, Thomas JR, Hanker LA, Richardson MA, Schuller DE.Otolaryngology Head and Neck Surgery. 4th Ed. Volume 3: Pennsylvania: Elsevier Mosby; 2005;p. 1970.

8 Saito M, Imagawa H, Sakakibara K, Tayama N, Nibu K, Amatsu M. High speed digital imaging and electroglottography of tracheoesophageal phonation by Amatsu's method. Acta Otolaryngol. 2006 May; 126(5):521-5.

9 van As CJ. Tracheoesophageal Speech. A Multidimensional Assessment of Voice Quality. Institute of Phonetic Sciences, University of Amsterdam, Proceedings 24 (2001), 189-194.

10 Omori K, Kojima H, Nonomura M, Fukushima H. Mechanism of tracheoesophageal shunt phonation. Arch Otolaryngol Head Neck Surg. 1994 Jun;120(6):648-52.

11 Harries $M$, Morrison $M$. The role of stroboscopy in the management of a patient with a unilateral vocal fold paralysis. J Laryngol Otol. 1996; 110(2):141-143.

12 Robbins J, Christensen J, Kempster G. Characteristics of speech production after tracheoesophageal puncture: voice onset time and vowel duration. J Speech Hear Res. 1986 Dec;29(4):499-504. 